\title{
THE OLDEST RECORD OF LAMBEOSAURINAE IN EUROPE: PHYLOGENETIC IMPLICATIONS
}

\author{
Simone Conti ${ }^{1} \oplus$, Albert Prieto-Márquez ${ }^{2}$, Albert Sellés Garcia ${ }^{2}$, Bernat Vila², Àngel Galobart², \\ Michael James Benton ${ }^{1}$
}

${ }^{1}$ School of Earth Sciences, University of Bristol, Life Sciences Building, 24 Tyndall Avenue, Bristol BS8 1TQ, United Kingdom. sc17278@ bristol.ac.uk

${ }^{2}$ Institut Català de Paleontologia Miquel Crusafont, Universitat Autònoma de Barcelona, Carrer de l'Escola Industrial, 23, 08201, Sabadell, Barcelona, Spain.

\section{KEYWORDS: \\ Dinosaur; \\ Lambeosaurinae; \\ Cretaceous; \\ Maastrichtian; \\ Europe.}

\section{Bullet-Points Abstract}

- Oldest lambeosaurine dinosaur from Europe.

- Close phylogenetic relationships among European and Asian lambeosaurine dinosaurs.

\section{INTRODUCTION}

During the Late Cretaceous Europe was an archipelago where the so called Ibero-Armorica landmass (present-day Iberian Peninsula plus the Pyrenean and Provence regions of France) was the largest island (Fondevilla et al., 2016). The study of the faunas in the Iberico-Armorican Island has evidenced a 10ma dinosaur succession with a gradual faunal turnover. In this, the pre-turnover dinosaur assemblages (mainly titanosaurids, rhabdodontids, and nodosaurids) were replaced by post-turnover assemblages, where lambeosaurine hadrosauroids featured predominantly (Vila et al., 2016). Lambeosaurines in Europe are represented by four taxa: Pararhabdodon isonensis Casanovas-Casadellas et al., 1993, Arenysaurus ardevoli Pereda-Superbiola et al., 2009, Blasisaurus canudoi Cruzado-Caballero et al., 2010 and Canardia garonnensis Prieto-Márquez et al., 2013, belonging to three different tribes (Prieto-Márquez et al., 2013). All these taxa are reported from sites dated to late Maastrichtian from the southern and northern Pyrenees. Here we update the oldest record of European lambeosaurines.

\section{Materials ANd Methods}

The remains supporting this occurrence have been collected from strata of the La Posa Formation cropping out at the Els Nerets locality (early Maastrichtian, Tremp Group, eastern Tremp Syncline, Catalonia). The material consists of several vertebrae, a humerus, an ulna, two ischia, two femora, a fibula and other fragmentary elements representing two individuals, one of which reached adulthood.

\section{Discussions ANd Conclusions}

This lambeosaurine taxon shares characters with Tsintaosaurus spinorhinus Young, 1958, from the Campanian of China, while displaying notable differences from Pararhabdodon isonensis from the uppermost Maastrichtian of the southern Pyrenees. The phylogenetic position of the lambeosaurine from Els Nerets was inferred using Maximum Parsimony and Bayesian analyses, confirming that it is a member of Tsintaosaurini.

The relatively small body size of this animal, compared to other lambeosaurines, such as T. spinorhinus, suggests the possibility of insularity affecting the life history of the Iberian form.

This study reinforces the Eurasian distribution of basal lineages of lambeosaurine hadrosaurids, indicating a greater diversity in the Tsintaosaurini tribe than previously realized. Further, the new fossils add information to the complexity of the faunal turnover that occurred in the Ibero-Armorican Island at the Campanian-Maastrichtian boundary. The event was triggered by multiple Asian dispersal waves, leading to a Campanian fauna dominated by rhabdodontids ornithopods, nodosaurid ankylosaurs and titanosaurs sauropods, being subsequently replaced primarily by lambeosaurines during Maastrichtian times.

\section{REFERENCES}

Casanovas-Cladellas M. L., Santafé-Llopis J. V. \& Isidoro-Llorens A. (1993) Pararhabdodon isonensen. n. gen. n. sp. (Dinosauria). Estudio morfológico, radiotomografico y consideraciones biomecanicas. Paleontologia I Evoluciò. 2-27: 121-131.

Cruzado-Caballero P., Pereda-Superbiola X. \& Ruiz-Omencada J. I. (2010) Blasisaurus canudoi gen. et sp. nov., a new lambeosaurine dinosaur (Hadrosauridae) from the Latest Cretaceous of Arén (Huesca, Spain). Canadian Journal of Earth Sciences, 47: 1507-1517. 


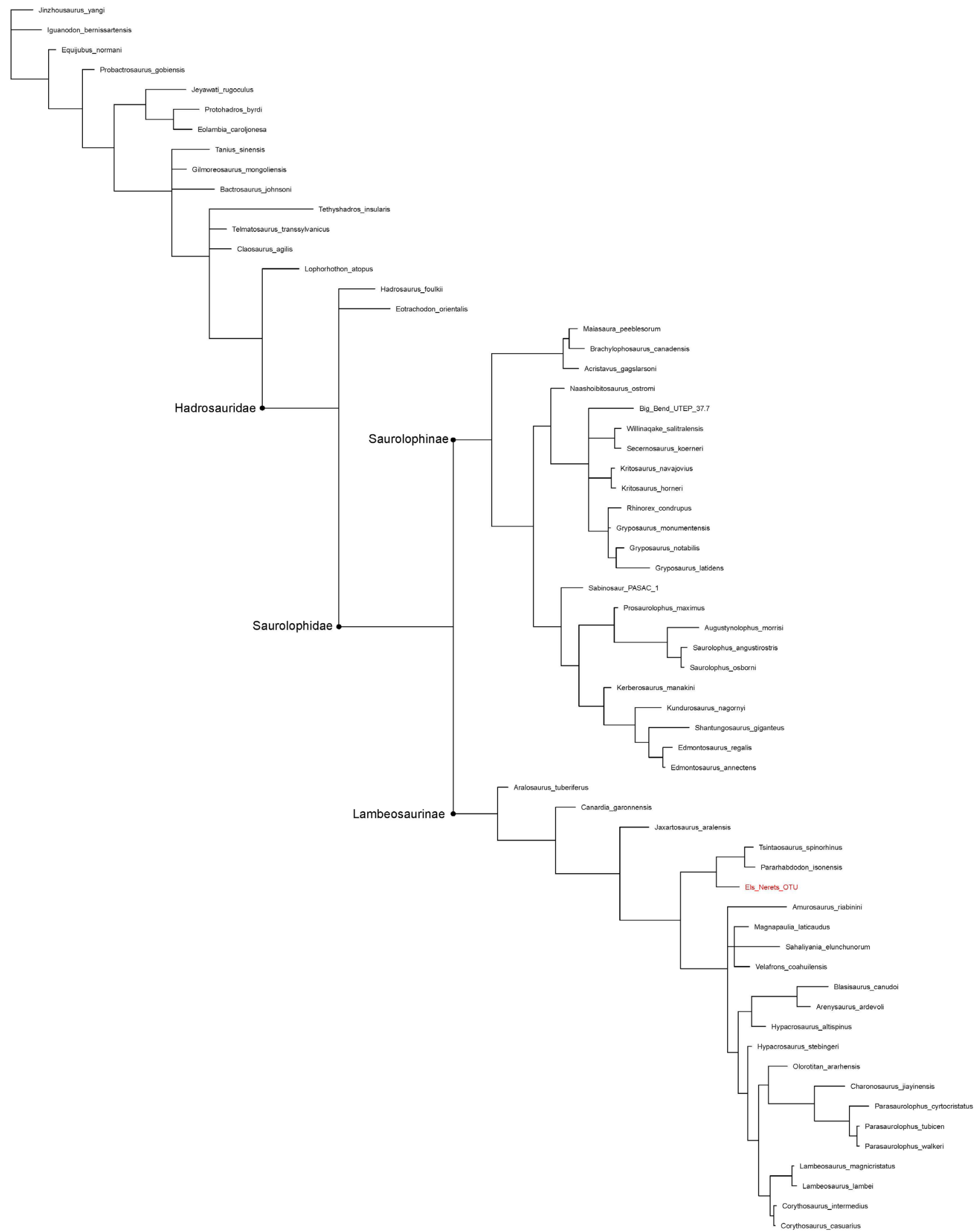

Fig. 1. Consensus tree of the Bayesian analysis, showing the phylogenetic relationships of Els Nerets specimens as basal Lambeosaurinae, close to Tsintaosaurus spinorhinus. The Bayesian analisis was conducted using the JC model, assuming equal rates of changes, running 1'000'000 analyses starting from four random trees. Stationarity was achieved with a standard deviation of split frequencies of 0.015 . The matrix used for the analyses is an updated version of that of Prieto-Márquez \& Gutarra (2016). 
Fondevilla V., Dinarès-Turell J. \& Oms O. (2016) The Chronostratigraphic framework of the South-Pyrenean Maastrichtian succession reappraised: implications for basin development and end-Cretaceous dinosaur faunal turnover. Sedimentary Geology, 337: 55-68.

Pereda-Superbiola X., Canudo J. I., Cruzado-Caballero P., Barco J. L., López-Martínez N., Oms O. \& Ruiz-Omeñaca J. I. (2009) The last hadrosaurid dinosaurs of Europe: a new lambeosaurine from the Uppermost Cretaceous of Aren (Huesca, Spain). Comptes Rendus Palevol, 8: 559-572.

Prieto-Márquez A., Dalla Vecchia F. M., Gaete R. \& Galobart À. (2013) Diversity, relationships, and biogeography of the lambeosaurine dinosaurus from the European Archipelago, with description of the new ara- losaurin Canardia garonnensis. PLoS ONE, 8 (7): e69835.

Prieto-Márquez A. \& Gutarra S. (2016) The 'duck-billed' dinosaurs of Careless Creek (Upper Cretaceous of Montana, USA), with comments on hadrosaurid ontogeny. Journal of Paleontology, 90: 133-146. doi:10.1017/ jpa.2016.42

Vila B., Sellés A. G. \& Brusatte S. L. (2016) Diversity and faunal changes in the latest Cretaceous dinosaur communities of southwestern Europe. Cretaceous Research, 57: $552-564$

Young C. C. (1958) The dinosaurian remains of Laiyang, Shantung. Paleontologica Sinica, New Series C 16: 53138

Manuscript received 14 July 2018

Received after revision 15 October 2018 Accepted - October 2018 